\title{
Foliar Application of Nitrogen Affects Metabolism and Productivity of Soybean
}

\author{
Walquíria F. Teixeira ${ }^{1}$, Evandro B. Fagan ${ }^{2}$, Antônio P. M. Machado ${ }^{3}$, Daniel Fortune ${ }^{4}$ \& Fernando R. Moreira $^{3}$ \\ ${ }^{1}$ Crop Science Department, "Luiz de Queiroz" College of Agriculture, University of Sao Paulo, Piracicaba, SP, \\ Brazil \\ ${ }^{2}$ University Center of Patos de Minas, Patos de Minas, Minas Gerais, Brazil \\ ${ }^{3}$ Hexion, Inc. Curitiba, Paraná, Brazil \\ ${ }^{4}$ Hexion, Inc. Stafford, Texas, USA \\ Correspondence: Walquíria F. Teixeira, Crop Science Department, "Luiz de Queiroz" College of Agriculture, \\ University of Sao Paulo, 13418-970, Piracicaba, SP, Brazil. E-mail: walquiria_bio@hotmail.com
}

Received: April 22, 2021

doi:10.5539/jas.v13n10p31
Accepted: July 1, 2021

Online Published: September 15, 2021

URL: https://doi.org/10.5539/jas.v13n10p31

\begin{abstract}
Soybean is one of the world's most economically important crops and several factors can affect the productivity of this culture. Among these factors is the supply of needed nitrogen, especially in the reproductive stage, as it acts in photosynthetic activity and in grain filling. In view of this, the objective of our work was to evaluate the effect of foliar application of nitrogen in different reproductive stages in soybean culture. Two sources of nitrogen were used: conventional urea and urea-formaldehyde/triazone, both applied in reproductive stages $\mathrm{R}_{2}$, $\mathrm{R}_{3}, \mathrm{R}_{4}$, or $\mathrm{R}_{5}$, as well as a control treatment without foliar application of nitrogen. Plants submitted to foliar application of urea-formaldehyde/triazone showed an increase in nitrogen metabolism (percentage of nitrogen derived from the atmosphere [Ndfa] and nitrate reductase activity [NR]), an increase in peroxidase (POD), and the consequent reduction in hydrogen peroxide $\left(\mathrm{H}_{2} \mathrm{O}_{2}\right)$ in all stages of application of this treatment. When urea-formaldehyde/triazone was applied in $\mathrm{R}_{4}$, it resulted in a $7 \%$ increase in yield. The application of conventional urea in reproductive stages $\mathrm{R}_{4}$ and $\mathrm{R}_{5}$ increased nitrogen metabolism and resulted in an increase in yield by $4 \%$. However, conventional urea reduced yield when applied in stages $R_{2}$ and $R_{3}$. The use of low doses of foliar nitrogen in stages $\mathrm{R}_{4}$ and $\mathrm{R}_{5}$, increased nitrogen metabolism in soybean plants. The timing of the application has a direct impact on the results with the slow-release nitrogen (urea formaldehyde /triazone) showing better results when applied in stage $\mathrm{R}_{4}$ and better results for conventional urea in $\mathrm{R}_{5}$.
\end{abstract}

Keywords: Glycine $\max$ (L.) Merrill., urea-formaldehyde/triazone, conventional urea

\section{Introduction}

Brazil is the world's largest producer of soybean. According to the National Supply Company (CONAB, 2021), the national soybean production in the 2020/2021 season was 135.9 million tons in an area of 38.5 million hectares. Brazilian exports of soy complex, which includes grain, soy oil and soy meal, totaled US\$ 136 billion in 2019; equivalent to $16.98 \%$ of all national exports (CONAB, 2021). Therefore, soyben is one of the most important crops for agribusiness and for the Brazilian trade balance.

Crop genotype, the environment, and crop management are directly related to yields, and nutrient supply must be in accordance with plant requirements in the appropriate form, time, and quantities (Pacentchuk, Novakowiski, \& Sandini, 2014). Nitrogen (N) is one of the main nutrients required by soybean culture and most of this $\mathrm{N}$ comes from the symbiotic relationship with Bradyrhizobium elkanlii and Bradyrhizobium japonicum that can occur naturally in the environment or are provided through seed inoculation (Hungary et al., 2001). However, to maximize the productivity of soybean, different management practices are adopted, among them the foliar application of $\mathrm{N}$.

Supply of $\mathrm{N}$ in foliar application has received great attention, as it is one of the main components of the photosynthetic system. Supply of N in adequate quantities positively influences the physiological, biochemical, and morphological characteristics of plants, in addition to being a fundamental nutrient for the expression of maximum productive potential (Wilson et al., 2014). In different crops, $\mathrm{N}$ deficiency is related to the 
development of chlorosis due to the reduction of chlorophyll (Taiz et al., 2017). In soybean culture, $\mathrm{N}$ deficiency in the vegetative phase is related to chlorosis and the reduction in the size of leaflets (Borket et al., 1994; Prado et al., 2010). Several studies have been carried out with the application of different $\mathrm{N}$ sources in soybean crops (Hungary et al., 2006; Mendes et al., 2008; Marcon et al., 2017; Moreno et al., 2018; Pierozan Junior et al., 2020). However, there are still few studies related to $\mathrm{N}$ fertilizers based on urea-formaldehyde/triazone in soybeans, especially at different stages of plant development. Urea-formaldehyde/triazone fertilizers, classified as chemically modified because they have properties of gradual release of nitrogen (Clapp \& Parham, 1991; Widders, 1991; Clapp, 2001; Bondada et al., 2001), provide greater efficiency in the use of applied $\mathrm{N}$ and are the most promising in an attempt to maximize crop yields. Cassim et al. (2020) demonstrated that the foliar application of nitrogen in stage $\mathrm{R}_{3}$ is effective in parameters such as productivity in soybean crop.

However, we believe that different responses can be obtained from the application of $\mathrm{N}$ at different phenological stages, especially related to the reproductive period, a period with high nitrogen demand in the soybean crop.

Thus, the objective of this study was to evaluate the influence of foliar application of nitrogen based on urea-formaldehyde/triazone and conventional urea on physiological, biochemical, and phenological variables, as well as, grain productivity in soybean culture.

\section{Method}

The experiment was conducted in the experimental field of the Cooperativa Agropecuária do Alto Paranaíba (COOPADAP), located in the state of Minas Gerais, in the Alto Paranaíba region, municipality of Rio Paranaíba. This location, according to Köppen classification, has a tropical climate of altitude (Cwa), with average annual precipitation around $1540 \mathrm{~mm}$ and an average annual temperature of approximately $20^{\circ} \mathrm{C}$ (Peel, 2007).

Soil analysis was carried out before sowing and, based on this analysis, fertilization was calculated. According to the soil analysis (Table 1), it was not necessary to apply limestone to correct the soil. The maintenance fertilizer used was composed of $31.2 \mathrm{~kg} \mathrm{ha}^{-1}$ of N, $117 \mathrm{~kg} \mathrm{ha}^{-1}$ of P, $39 \mathrm{~kg} \mathrm{ha}^{-1}$ of K, $12.7 \mathrm{~kg} \mathrm{ha}^{-1}$ of Ca, $16.6 \mathrm{~kg} \mathrm{ha}^{-1}$ of S, $0.8 \mathrm{~kg} \mathrm{ha}^{-1}$ of B, and $0.2 \mathrm{~kg} \mathrm{ha}^{-1}$ of $\mathrm{Zn}$.

Table 1. Soil analysis $(0-20 \mathrm{~cm})$ of the experimental area

\begin{tabular}{|c|c|c|c|c|c|c|c|}
\hline $\mathrm{pH}$ & P-Me1 & P-rem & $\mathrm{K}^{+}$ & $\mathrm{Ca}^{2+}$ & $\mathrm{Mg}^{2+}$ & $\mathrm{Al}^{3+}$ & $\mathrm{H}+\mathrm{Al}$ \\
\hline In water & \multicolumn{3}{|c|}{---------------- $\mathrm{mg} \mathrm{dm} \mathrm{dm}^{-3}$-------------- } & \multicolumn{4}{|c|}{ - } \\
\hline 5.60 & 10.23 & 4.94 & 85.70 & 2.94 & 0.56 & 0.02 & 1.30 \\
\hline SB & $\mathrm{t}$ & & & $\mathrm{V}$ & $\mathrm{m}$ & \multicolumn{2}{|r|}{$\mathrm{OM}$} \\
\hline --------- & ----- c & $\mathrm{dm}^{-3}-$ & ------------ & ---- & -- \% --- & \multicolumn{2}{|r|}{-- dag $\mathrm{kg}^{-1}$} \\
\hline 3.72 & 3.74 & & & 74.11 & 0.5 & & 3.12 \\
\hline
\end{tabular}

Note. P-Mel and $\mathrm{K}^{+}$: Mehich 1 extractor; $\mathrm{Ca}^{+}, \mathrm{Mg}^{+}$and $\mathrm{Al}^{+}$: $\mathrm{KCl} 1 \mathrm{~mol} \mathrm{~L}^{-1}$ extractor; P-rem: Remaining phosphorus-phosphorus concentration of the equilibrium solution after stirring 1 hour with $10 \mathrm{mmol} \mathrm{L}^{-1} \mathrm{CaCl}_{2}$ solution containing $60 \mathrm{~g}$ of $\mathrm{P}(1: 10)$.

Sowing was carried out in October 2017 using the cultivar TEC 7849 IPRO with a spacing of $0.60 \mathrm{~m}$ between rows to maintain a population density of 240,000 plants ha ${ }^{-1}$. Each plot was composed of four rows, seven meters in length, with $0.45 \mathrm{~m}$ between rows, totaling an area of $12.6 \mathrm{~m}^{2}$. The area of each plot was constituted by the central lines, discarding $0.5 \mathrm{~m}$ at each end of the plot.

For weed control, the herbicide glyphosate was applied in stage $V_{3}$ (three nodes on the main stem) [650 grams of active ingredient (gai) at a rate of $2.1 \mathrm{~kg}$ of commercial product (cp) ha ${ }^{-1}$. Insect control was performed with teflubenzuron [150 gai $\mathrm{L}^{-1}$ at a rate of $0.30 \mathrm{~kg} \mathrm{cp} \mathrm{ha}^{-1}$ ] in stage $\mathrm{V}_{5}$ (five nodes on the main stem); chlorfenapyr [240 gai $\mathrm{L}^{-1}$ at the rate of $0.8 \mathrm{~L} \mathrm{cp} \mathrm{ha}^{-1}$ ] at stage $\mathrm{R}_{1 / 2}$ (beginning of flowering), and imidacloprid and bifenthrin [250 gai L $\mathrm{L}^{-1}, 50$ gai $\mathrm{L}^{-1}$, respectively, at the rate of $0.4 \mathrm{~L} \mathrm{cp} \mathrm{ha}^{-1}$ ] applied in $\mathrm{R}_{3}$ (start of pod development) and $\mathrm{R}_{5.1}$ (start of grain formation and filling).

Disease control was performed using pyraclostrobin and cyproconazole [200 gai $\mathrm{L}^{-1}, 80$ gai $\mathrm{L}^{-1}$, respectively, at the rate of 0.3 L p.c. ha ${ }^{-1}$ ], applied in stages $V_{5}$ and $R_{5.1}$; propiconazole and diphenoconazole [ 250 gai $\mathrm{L}^{-1}$, 259 gai

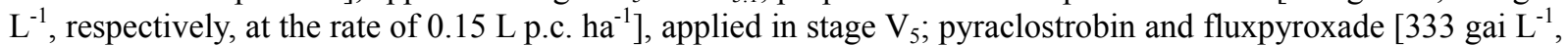
167 gai $\mathrm{L}^{-1}$, respectively, at the rate of $0.3 \mathrm{~L}_{\text {p.c. }} \mathrm{h}^{-1}$ ], applied at stage $\mathrm{R}_{1 / 2}$; bixafem, protioconazole and trifloxystrobin $\left[125\right.$ gai L $^{-1}, 175$ gai L $^{-1}, 150$ gai L ${ }^{-1}$, respectively, at the rate of $1.5 \mathrm{~L} \mathrm{p.c.} \mathrm{ha}{ }^{-1}$, applied in stages 
$\mathrm{R}_{1 / 2}, \mathrm{R}_{3}$ and $\mathrm{R}_{5.1}$; pyraclostrobin and benzovindiflupir $\left[100\right.$ gai $^{-1}, 50$ gai $\mathrm{L}^{-1}$, respectively, at the rate of $0.6 \mathrm{~L}$ p.c. $h a^{-1}$, applied in stage $\mathrm{R}_{3}$.

The experiment was designed with two $\mathrm{N}$ sources and four time of application with an additional treatment (control-without N), with eight replications (Table 2).

Table 2. Treatments with different source of nitrogen in foliar application

\begin{tabular}{ll}
\hline Stage of Aplication & Nitrogen Source \\
\hline Control & None \\
\hline$R_{2}$ & \\
$R_{3}$ & Urea-formaldehyde/triazone \\
$R_{4}$ & \\
$R_{5}$ & \\
\hdashline$R_{2}$ & Conventional Urea \\
$R_{3}$ & \\
$R_{4}$ & \\
$R_{5}$ & \\
\hline
\end{tabular}

Note. * Applied Dose: $2.5 \mathrm{~kg}$ Nitrogen per hectare.

Foliar applications were carried out with a pack sprayer pressurized with $\mathrm{CO}_{2}$ at 2 bar. For all foliar applications, the spray volume of $200 \mathrm{~L} \mathrm{ha}^{-1}$ was used.

The urea-formaldehyde/triazone fertilizer ( $\mathrm{N}$ Hexion) was a $28 \% \mathrm{~N}$ fertilizer composed of urea, intermediate-release methylene-urea compounds, and triazone; the latter two responsible for the gradual release of N. Slow-release compounds accounted for $70 \%$ of the composition with a solids content of $73 \%$. In comparison, the conventional urea used had $45 \% \mathrm{~N}$ in its composition.

\subsection{Evaluations}

\subsubsection{Biochemical Analyzes}

The antioxidant metabolism (lipid peroxidation, hydrogen peroxide, catalase enzymes, superoxide dismutase, and peroxidase) was evaluated. Additionally, nitrogen metabolism was assessed using biological fixation and the enzyme nitrate reductase. For all these analyses, completely expanded leaves, collected from the middle third of five plants, were used for each repetition.

\section{(1) Antioxidant Metabolism}

The determination of the activity of antioxidant enzymes was carried out in the $\mathrm{R}_{5.5}$ stage (pods with $76 \%$ to $100 \%$ of formed grains), at 109 days after sowing. The extraction of plant material was carried out according to the method of Kar and Mishra (1976). The determination of enzymatic activity was performed based on the protein content in the leaf with the protein being quantified using the method proposed by Bradford (1976). From this analysis, the activity of the enzyme superoxide dismutase (Beauchamp \& Fridovich, 1971), catalase (Peixoto et al., 1999) and peroxidase (Teisseire \& Guy, 2000) was determined. To further aid in the verification of oxidative stress in plants, the content of proline (Bates et al. 1973), hydrogen peroxide (Alexieva et al., 2001), and lipid peroxidation (Heath \& Packer, 1968) was quantified.

\section{(2) Nitrogen Metabolism}

The analysis of the enzyme nitrate reductase (NR) was carried out in $\mathrm{R}_{5.5}$ stage. The method was performed according to the method proposed by Mulder et al. (1959). The biological fixation was determined based on the levels of ureides, amino acids, and nitrate present in the stem of the plants in stages $R_{3}, R_{4}$ (pods fully developed) and $\mathrm{R}_{5.5}$. The material was dried in an oven with forced air circulation at a temperature of $65^{\circ} \mathrm{C}$ and then crushed with the aid of an IKA mill. For the determination of nitrate $\left(\mathrm{NO}_{3}{ }^{-}\right)$, total amino acids (Aa), and ureides, $200 \mathrm{mg}$ of plant material was transferred to a Falcon tube and combined with $10 \mathrm{~mL}$ of Milli-Q water. After this procedure, the material was incubated in a water bath at $45^{\circ} \mathrm{C}$ for one hour and then centrifuged at $10,000 \mathrm{rpm}$ for 15 minutes. The quantification of $\mathrm{NO}_{3}{ }^{-}$was performed by the method proposed by Cataldo et al. (1975). For the determination of total amino acids, the protocol of Yemm and Cocking (1955) with adaptations described in Herridge (1984) was used. The ureides were determined based on the method proposed by Young and Conway 
(1942). From the nitrate, amino acid, and ureide evaluations, the relative abundance of ureides (Rur) and the nitrogen derived from the atmosphere (Ndfa) was estimated according to equations proposed by Herridge and Peoples (1990).

\subsubsection{Dry Mass of Stem, Leaves and Pods}

Four plants were collected per repetition for evaluation in stage $R_{5.5}$. Subsequently, these were placed in individualized paper bags, identified, and dried at $65^{\circ} \mathrm{C}$ until constant mass was achieved to determine the dry matter mass. Weighing was performed using a digital scale with an accuracy of 0.01 gram.

\subsubsection{Productivity}

The plants were collected from the two central rows of each plot. The water content of the grains was determined and the yield (mass per unit area) was calculated with the water content corrected to $13 \%$. To measure the mass of the samples, a digital scale with an accuracy of 0.01 gram was used.

\subsection{Statistical Analysis}

The results obtained were analyzed for normality and homogeneity of variances and then the analyzed with One-Way Analysis of Variance with means being compared using Tukey's multiple comparisons test at a level of $5 \%$ significance.

A multivariate analysis was performed through Principal Component Analysis. All analyses were performed using the statistical software SAS 9.3 (SAS Institute, 2011).

\section{Results}

\subsection{Evaluations in $R_{3}$ Stage}

Application of two sources of $\mathrm{N}$ in $\mathrm{R}_{3}$ stage increased the total amino acids (Aa) in plants (Figure 1A), in comparison to application in $\mathrm{R}_{2}$ stage; however, there was no difference in comparison to the control. The application of Conventional Urea in the $\mathrm{R}_{2}$ and $\mathrm{R}_{3}$ stages reduced the ureides (Figure 1B) in comparison to the control.

When observing the percentage of Rur and Ndfa, it is noted that urea-formaldehyde/triazone was more efficient compared to conventional urea when applied in the $\mathrm{R}_{2}$ stage (Figures 1D and 1E), providing an increase of $20 \%$ and $18 \%$ for the variables Rur and Ndfa, respectively. 


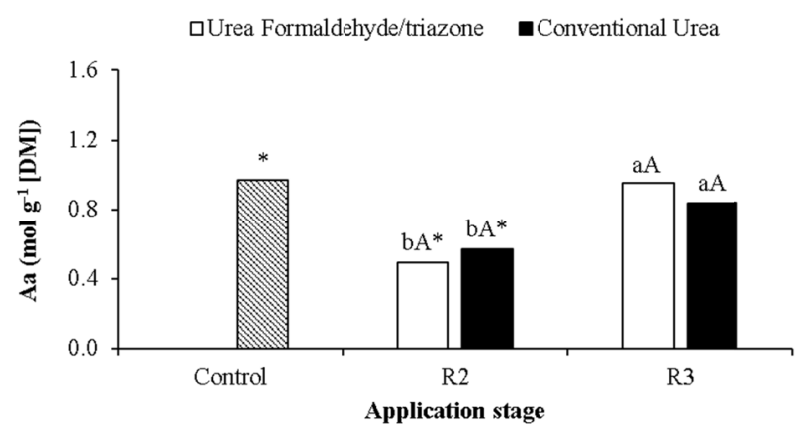

(A)

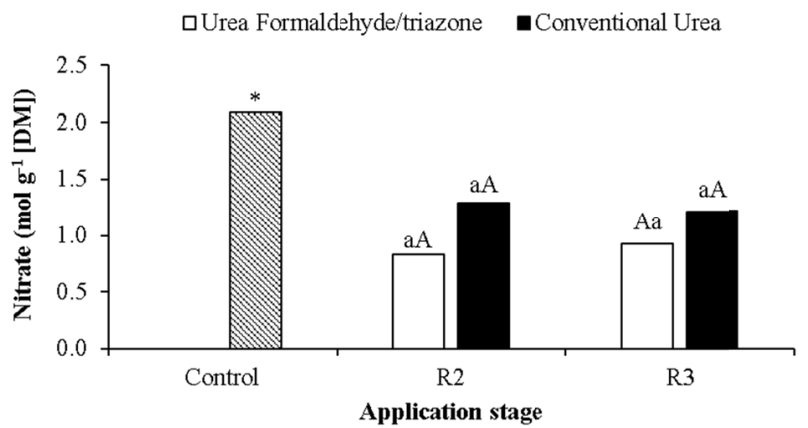

(C)

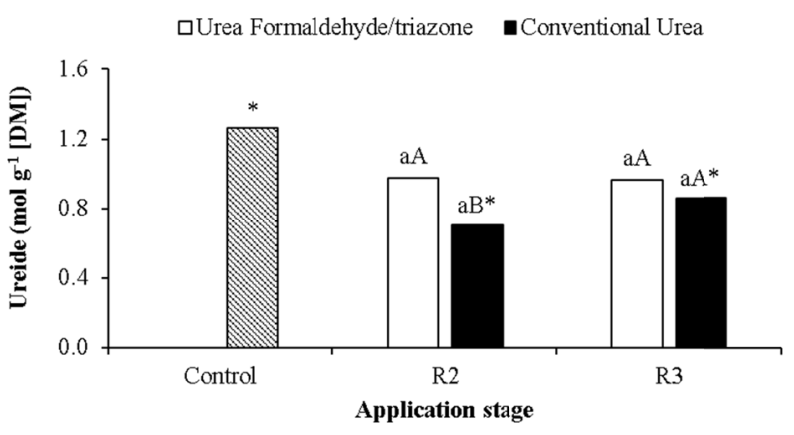

(B)

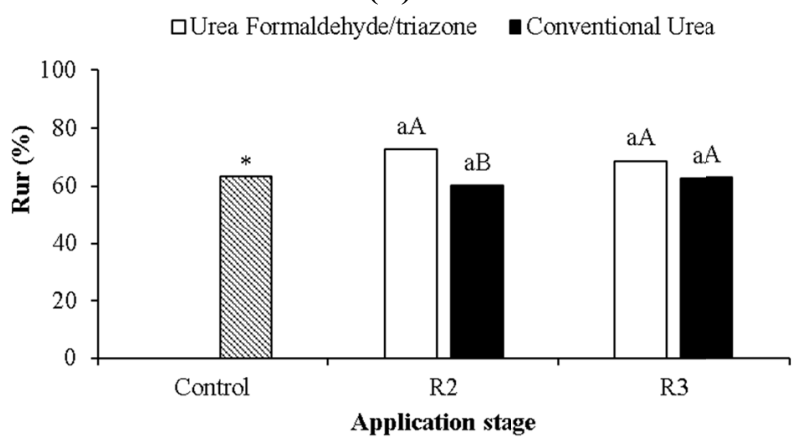

(D)

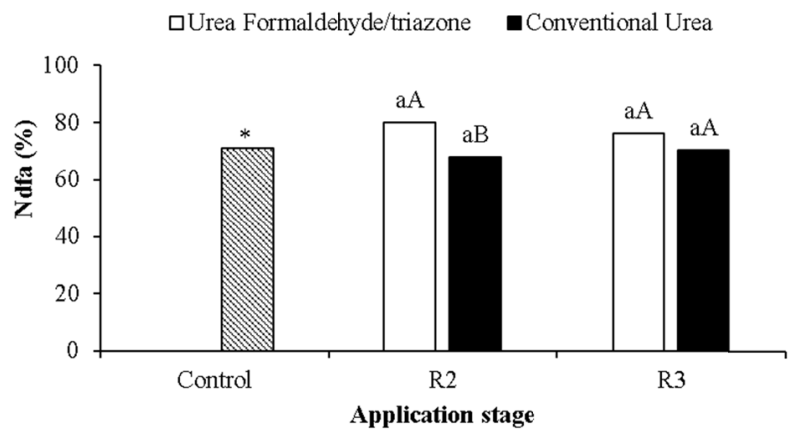

(E)

Figure 1. Effects of foliar application of urea-formaldehyde/triazone and conventional urea on the soybean total amino acid (A), ureide (B), Nitrate (C), relative abundance of ureide (D) and percentage of nitrogen derived from the atmosphere (E). Season 2017/2018. Means followed by the same capital letters between source of N, and lower-case letters between stage of apllication do not differ significantly from each other, using the Tukey test at $5 \%$ significance. * Means that differ significantly to the Control treatment using Dunnett's test

\subsection{Evaluations in $R_{4}$ Stage}

In the evaluations carried out in the $\mathrm{R}_{4}$ stage, it was observed that the application of both sources of nitrogen did not affect increments in the amino acid content in the plants (Figure 2A). However, the use of formaldehyde/triazone urea in the $\mathrm{R}_{2}$ stage, reflected in the increase of $38 \%, 12 \%$, and $10 \%$ in the content of ureides, Rur, and Ndfa, respectively, in relation to the control (Figures 2B, 2D and 2E). The application of urea in $R_{2}$ and $R_{4}$ provided the reduction in the content of Rur and Ndfa in the plants (Figures 2D and 2E), in relation to the urea-formaldehyde/triazone. The application of urea-formaldehyde/triazone provided increase of content of ureide, Rur and Ndfa in the plants in $\mathrm{R}_{2}$ stage in relation to the other stages of application (Figures 2B, 2D and $2 \mathrm{E})$. And Conventional urea is better in $\mathrm{R}_{3}$ stage compared to the other stages of application. 


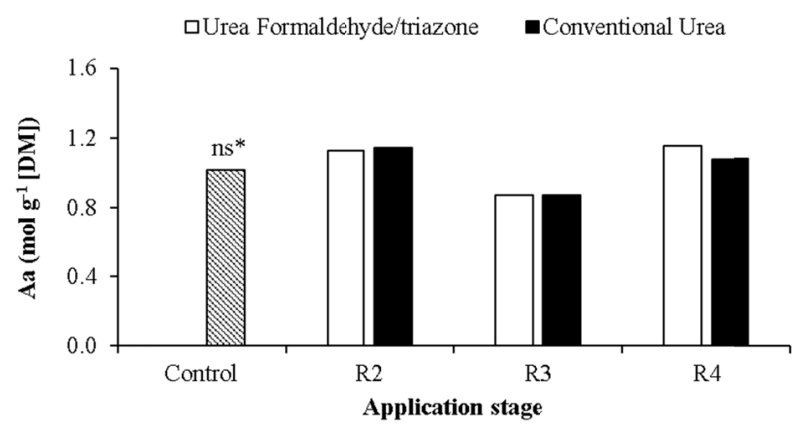

(A)

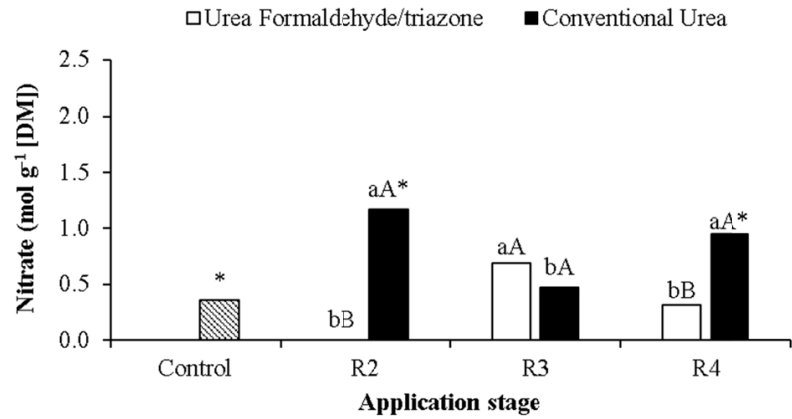

(C)

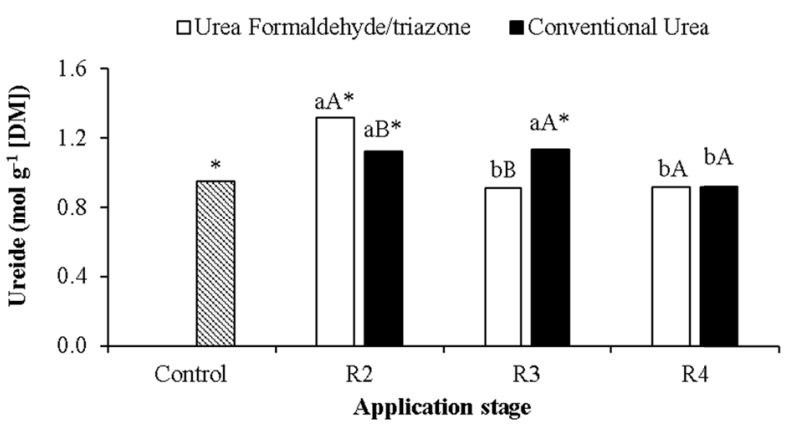

(B)

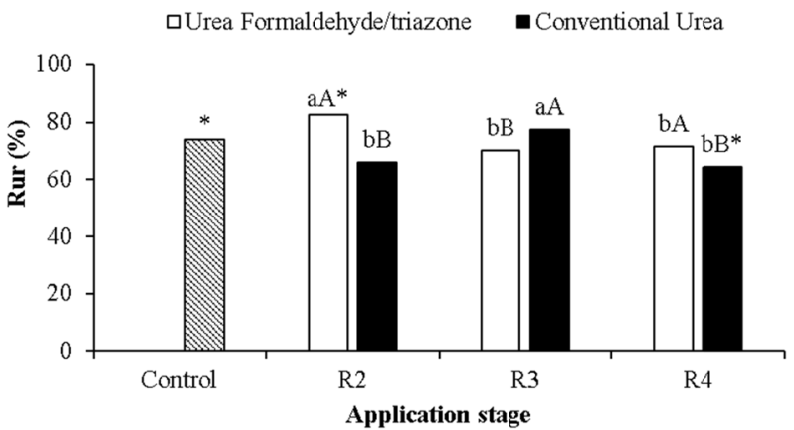

(D)

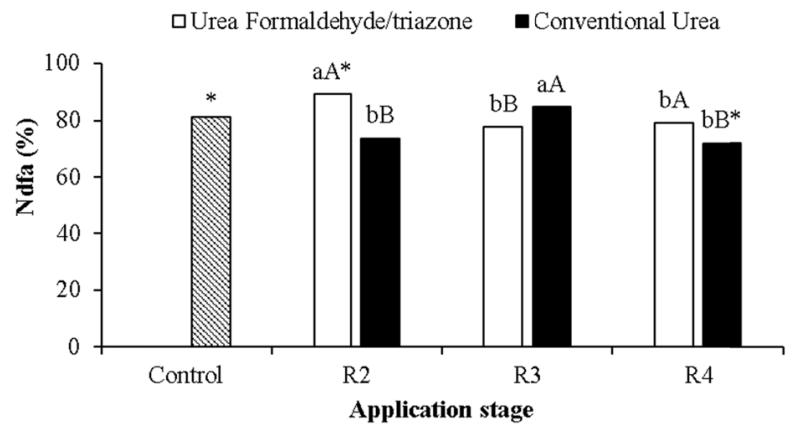

(E)

Figure 2. Effects of use foliar application of urea formaldehyde/triazone and conventional urea on soybean total amino acid (A), ureide (B), Nitrate (C), relative abundance of ureide (D) and percentage of nitrogen derived from the atmosphere (E). Means followed by the same capital letters between source of $\mathrm{N}$, and lower-case letters between stage of apllication do not differ significantly from each other, using the Tukey test at $5 \%$ significance.

Ns: not significant. * Means that differ significantly to the Control treatment using Dunnett's test

\subsection{Evaluations in R5.5 Stage}

At this stage, there was no significant difference in the dry mass of stem and leaves (Figures 3A and 3B). However, all the treatments showed an increase in Rur and Ndfa (Figures 3F and 3G), in comparison to the control. In contrast all treatments showed reduced content of amino acids (Figure 3D).

The application of conventional urea in $\mathrm{R}_{4}$ stage was more efficient in the PDM (Figure 3C) compared to application in othes stages. Additionally, application of conventional urea in stage R4 increase PDM by $20 \%$ compared to urea-formaldehyde/triazone.

The application of urea-formaldehyde/triazone in $\mathrm{R}_{4}$ increased NR by $108 \%$ in comparison to the control, and $83 \%$ in comparison to conventional urea (Figure $3 \mathrm{H}$ ). Conventional urea showed a better response when applied in $\mathrm{R}_{5}$ stage in comparison to the others stages of application. 


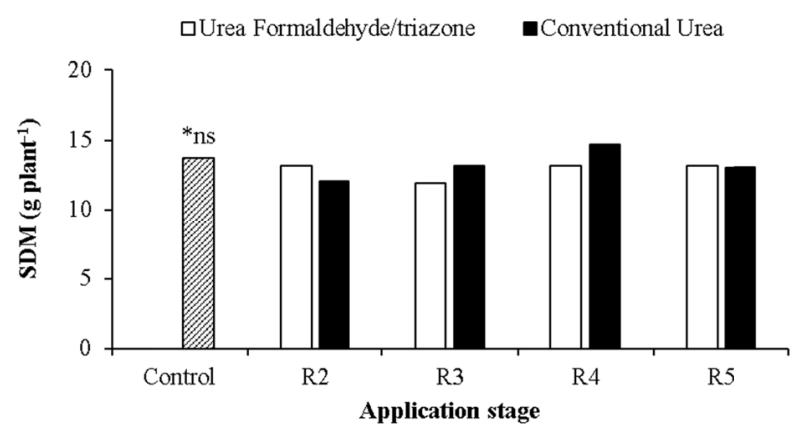

(A)

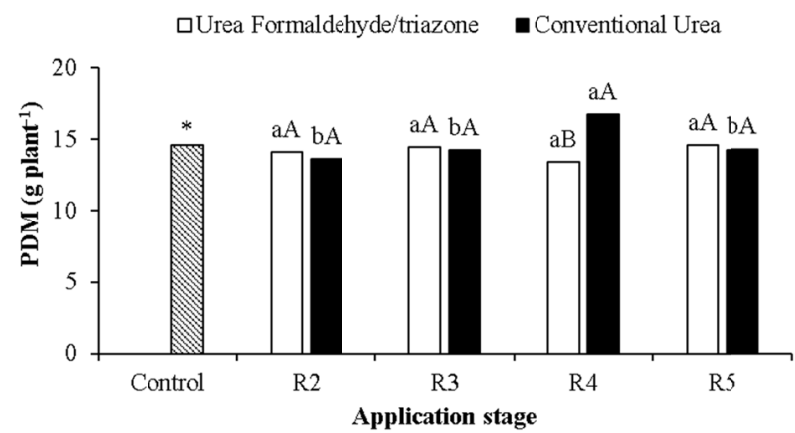

(C)

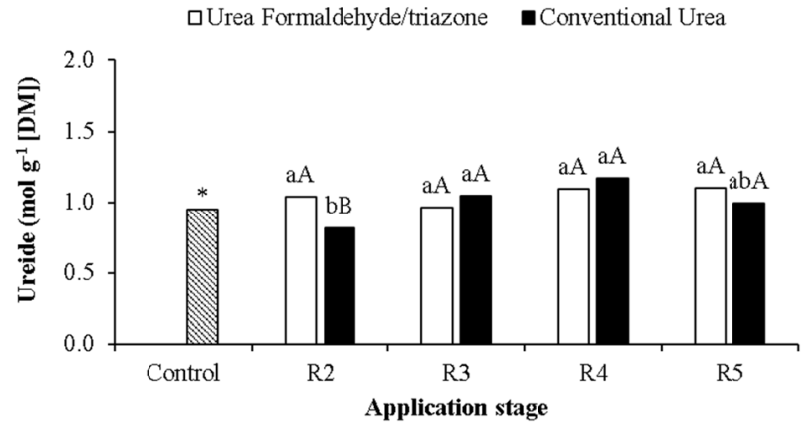

(E)

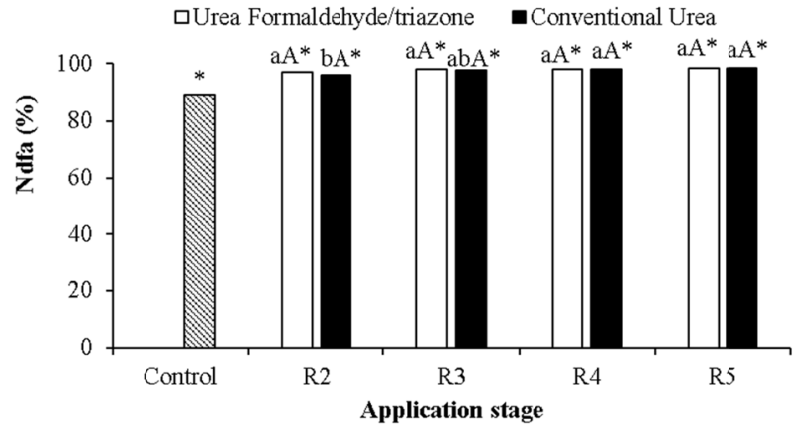

(G)

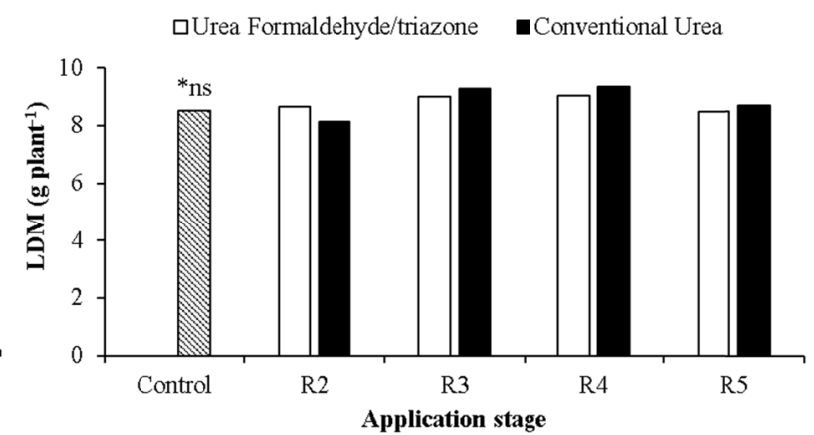

(B)

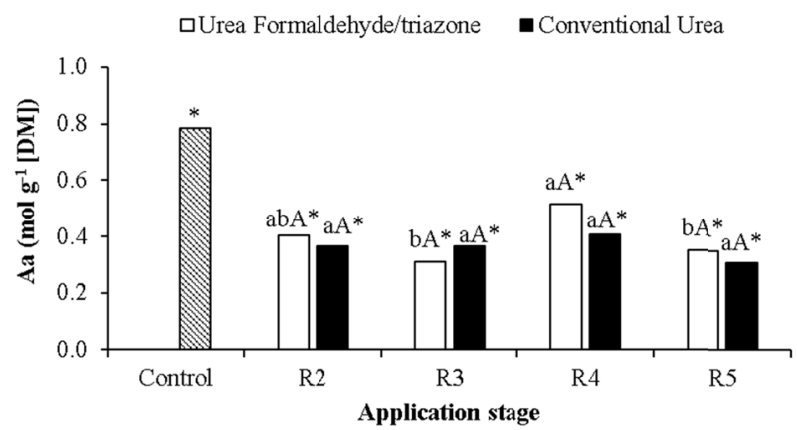

(D)

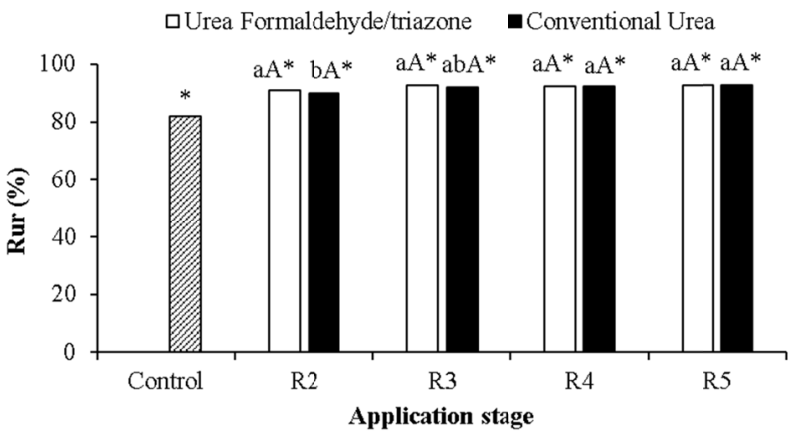

(F)

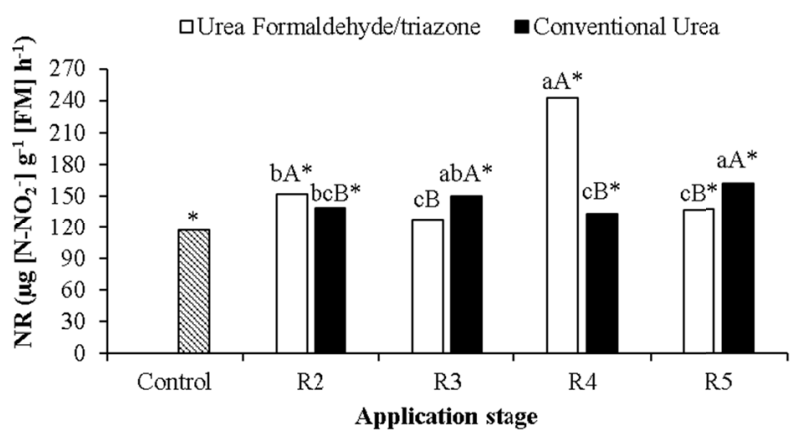

(H)

Figure 3. Effects of the use of foliar application of urea formaldehyde/triazone and conventional urea on soybean stem dry mass (A), leaf dry mass (B), pod dry mass (C), total amino acid (D), ureide (E), relative abundance of

ureide $(F)$, percentage of nitrogen derived from the atmosphere $(\mathrm{G})$ and nitrate reductase activity $(\mathrm{H})$.

Evaluations performed at $\mathrm{R}_{5.5}$ stage. Means followed by the same capital letters between source of $\mathrm{N}$, and lower-case letters between stage of apllication do not differ significantly from each other, using the Tukey test at $5 \%$ significance. ns: not significant. * Means that differ significantly to the Control treatment using the Dunnett test 
The application of urea-formaldehyde/triazone in $\mathrm{R}_{4}$ stage increased POD by $88 \%$, protein content in the leaves by $9 \%$ (Figure $4 \mathrm{G}$ ), and productivity by $7 \%$ (Figure $4 \mathrm{H}$ ) compared to the control treatment.

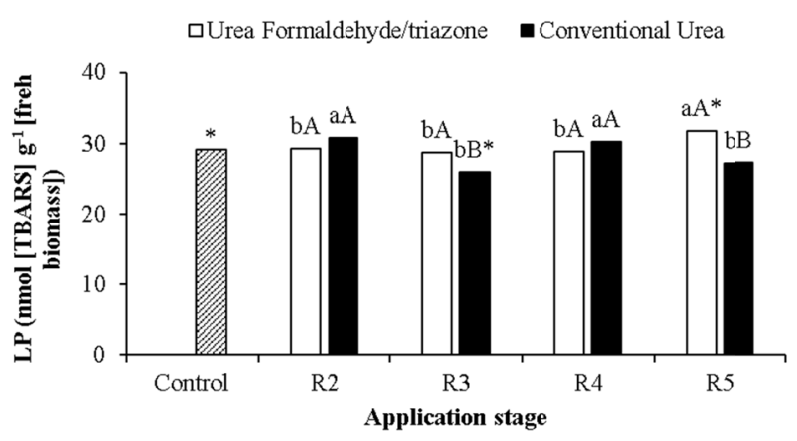

(A)

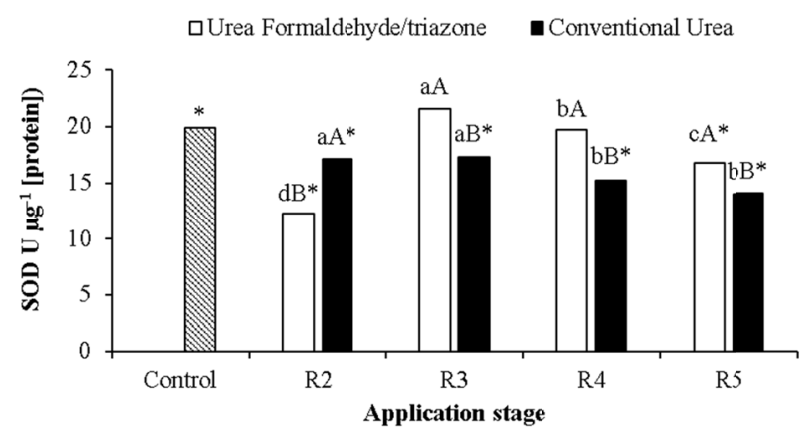

(C)

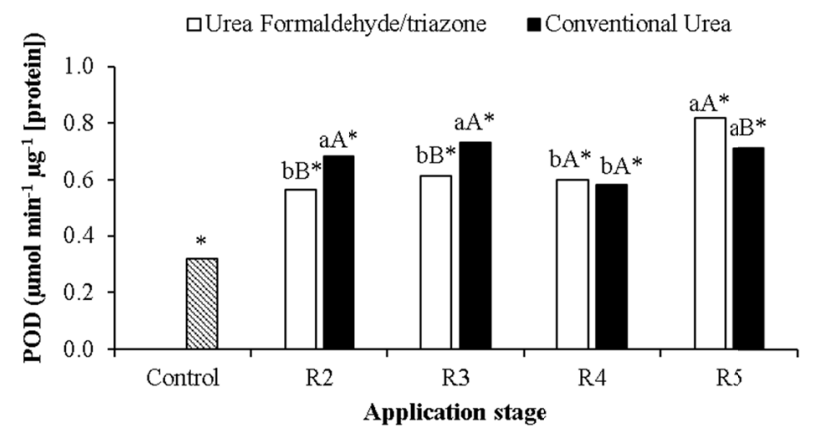

(E)

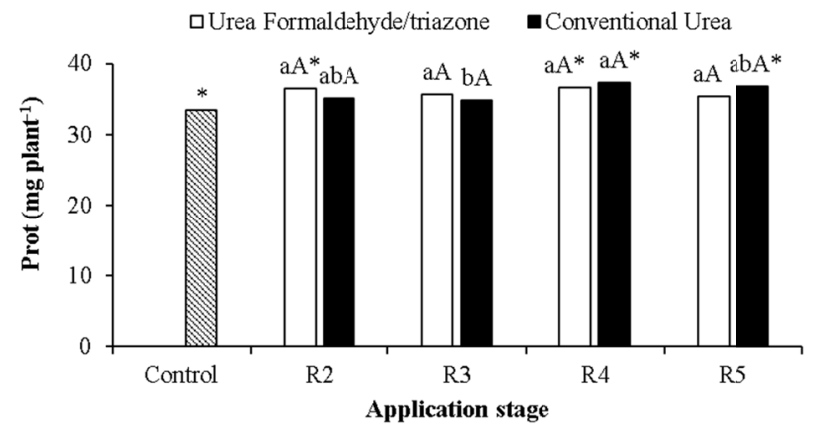

(G)

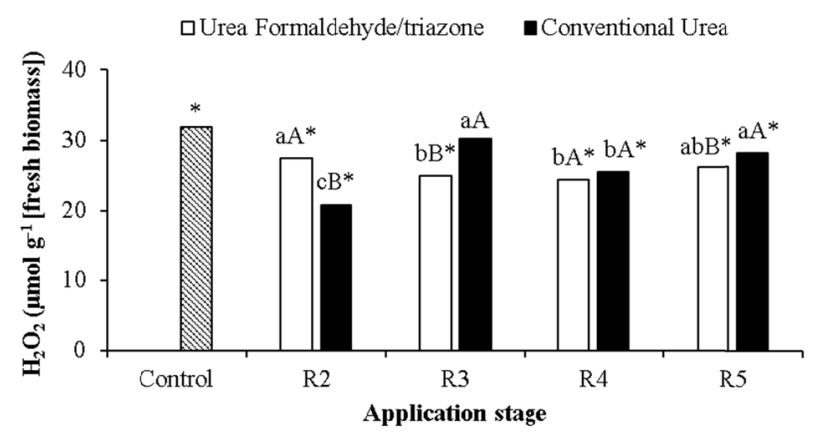

(B)

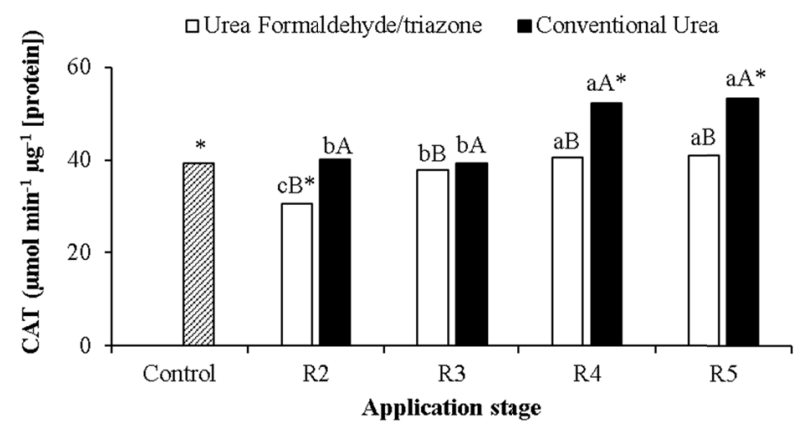

(D)

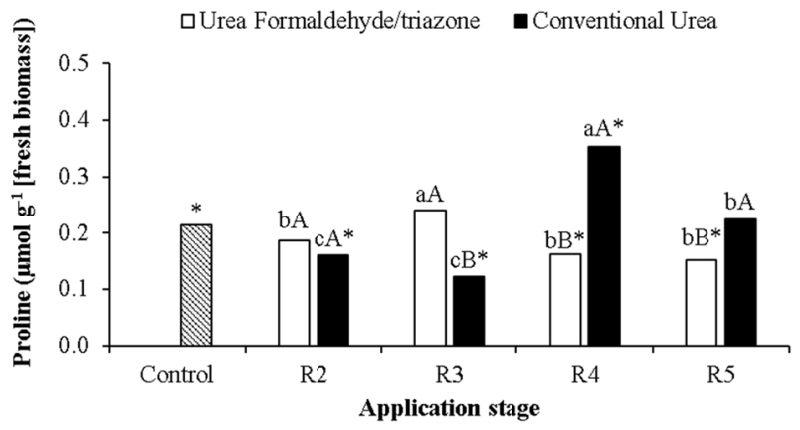

(F)

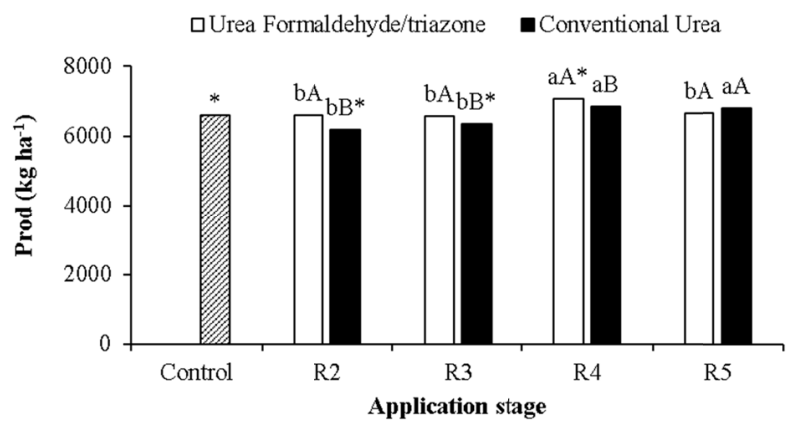

(H)

Figure 4. Effects of use foliar application of urea formaldehyde/triazone and conventional urea on soybean lipid peroxidation (A), hydrogen peroxide content (B), superoxide dismutase (C), catalase (D), peroxidase (E), proline content $(\mathrm{F})$, protein content $(\mathrm{G})$. Evaluations performed at $\mathrm{R}_{5.5}$ stage. Means followed by the same capital letters between source of $\mathrm{N}$, and lower-case letters between stage of apllication do not differ significantly from each other, using the Tukey test at $5 \%$ significance. *Means that differ significantly to the Control treatment using the Dunnett's test 
The use of urea-formaldehyde/triazone in $\mathrm{R}_{5}$ incresed LP by $9 \%$ (Figure $4 \mathrm{~A}$ ), POD by $88 \%$ (Figure $4 \mathrm{E}$ ), and reduced SOD by $15 \%$ (Figure $4 \mathrm{C}$ ), $\mathrm{H}_{2} \mathrm{O}_{2}$ content by $23 \%$ (Figure $4 \mathrm{~B}$ ), and proline by $29 \%$ (Figure $4 \mathrm{~F}$ ) compared to the control. In addition, comparing the two sources of $\mathrm{N}$, the application of urea-formaldehyde/triazone in $\mathrm{R}_{2}$, $R_{3}$, and $R_{4}$ stages increased productivity in comparison to conventional urea (Figure $4 \mathrm{H}$ ).

In addition, plants treated with conventional urea in $\mathrm{R}_{3}$, showed a $43 \%$ reduction in proline content (Figure $4 \mathrm{~F}$ ), and a $4 \%$ reduction in productivity (Figure $4 \mathrm{H}$ ), compared to the control.

Conversely, the application of conventional urea in $\mathrm{R}_{4}$ increased the activity of CAT (Figure 4D), POD (Figure 4E), proline content (Figure $4 \mathrm{~F}$ ) and protein (Figure 4G), and led to a $7 \%$ increase in productivity (Figure $4 \mathrm{H}$ ), in comparison to the control.

From principal components analysis (PCA), three variables were obtained with the greatest representativeness (Figure 5), protein and Ndfa as $\mathrm{PC}_{1}$ and productivity as $\mathrm{PC}_{2}$. These three variables showed greater eigenvector weights (Table 3). The productivity correlated with the proline, protein, and nitrate reductase. According to PCA, the use of urea-formaldehyde/triazone at $\mathrm{R}_{2}$ and $\mathrm{R}_{4}$, and the use of conventional urea at $\mathrm{R}_{4}$ and $\mathrm{R}_{5}$ provided higher productivity. The control treatment presented high values of the SOD and $\mathrm{H}_{2} \mathrm{O}_{2}$.

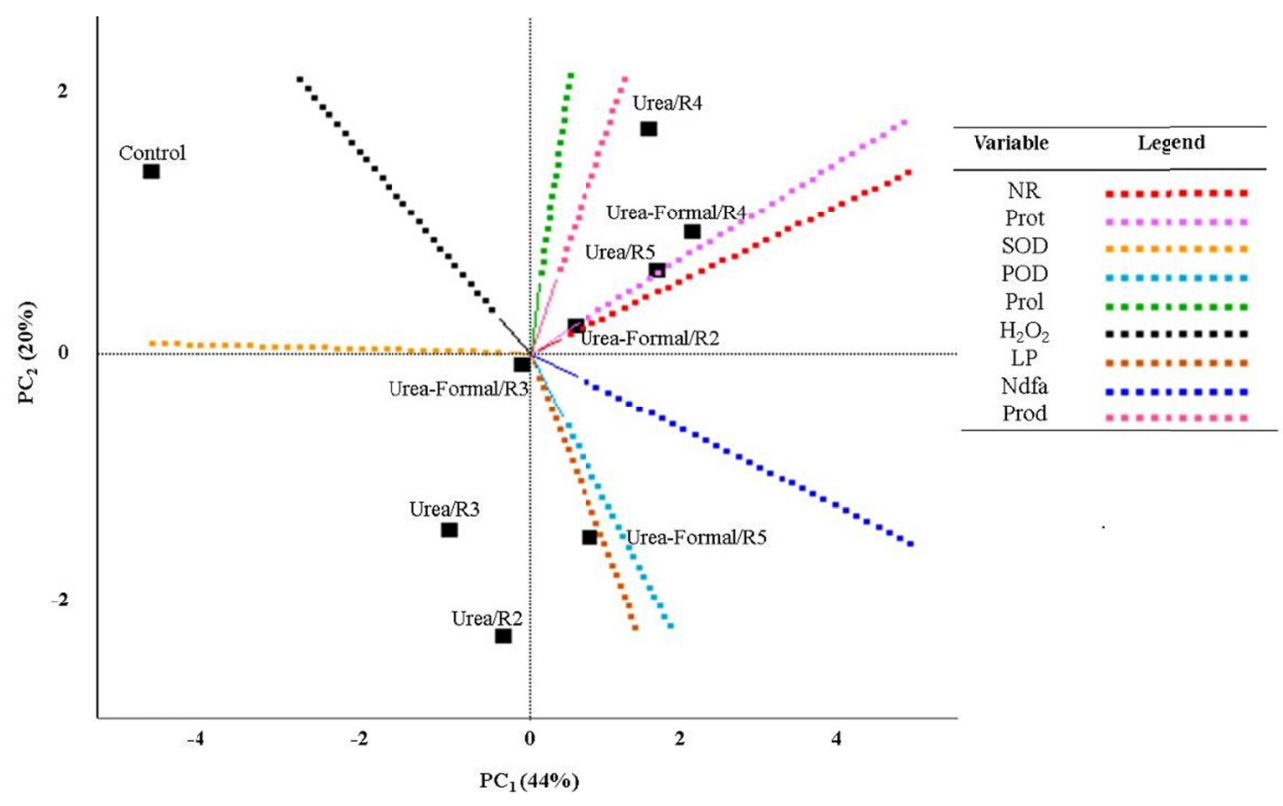

Figure 5. Byplot obtained from PCA of main components of the results of foliar application of urea formaldehyde/triazone (Urea-Formaldehyde) and conventional urea (Urea), at $\mathrm{R}_{2}, \mathrm{R}_{3}, \mathrm{R}_{4}$ and $\mathrm{R}_{5}$ stage. Soybean leaf activity of nitrate reductase-NR, protein content-Prot, superoxide dismutase activity-SOD, peroxidase activity-POD, proline content-Prol, hydrogen peroxide content- $\mathrm{H}_{2} \mathrm{O}_{2}$, lipid peroxidation-PL, percentage of nitrogen derived from the atmosphere-Ndfa, and productivity-Prod. Field experiment. Season 2018/2019

Table 3. Eigenvalues, percentage of variance, cumulative variance, eigenvectors for different principal components

\begin{tabular}{lllllll}
\hline \multirow{2}{*}{ Principal component (PC) } & \multirow{2}{*}{ Eigen-values } & \multirow{2}{*}{ Percentage of variance } & Cumulative variance & \multicolumn{4}{c}{ Eigenvectors } \\
\cline { 5 - 7 } & & & Variable & $\mathrm{PC}_{1}$ & $\mathrm{PC}_{2}$ \\
\hline 1 & 3.11 & 0.44 & 0.44 & NR & 0.55 & 0.14 \\
2 & 1.84 & 0.20 & 0.64 & Protein & $0.92^{1}$ & 0.31 \\
3 & 1.59 & 0.12 & 0.76 & SOD & -0.39 & 0.00 \\
4 & 1.29 & 0.10 & 0.86 & POD & 0.63 & -0.67 \\
5 & 0.67 & 0.07 & 0.93 & Proline & 0.19 & 0.71 \\
6 & 0.43 & 0.05 & 0.98 & $\mathrm{H}_{2} \mathrm{O}_{2}$ & -0.56 & 0.36 \\
7 & 0.05 & 0.01 & 0.99 & LP & 0.10 & -0.14 \\
8 & 0.01 & 0.01 & 1.00 & Ndfa & $0.90^{1}$ & -0.25 \\
9 & 0.00 & 0.00 & 1.00 & Prod & 0.48 & $0.75^{1}$ \\
\hline
\end{tabular}

Note. ${ }^{1}$ Values with higher weights within principal component (PC). 
A synthesis of the results obtained by applying urea formaldehyde/triazone and conventional urea is summarized in Figure 6.
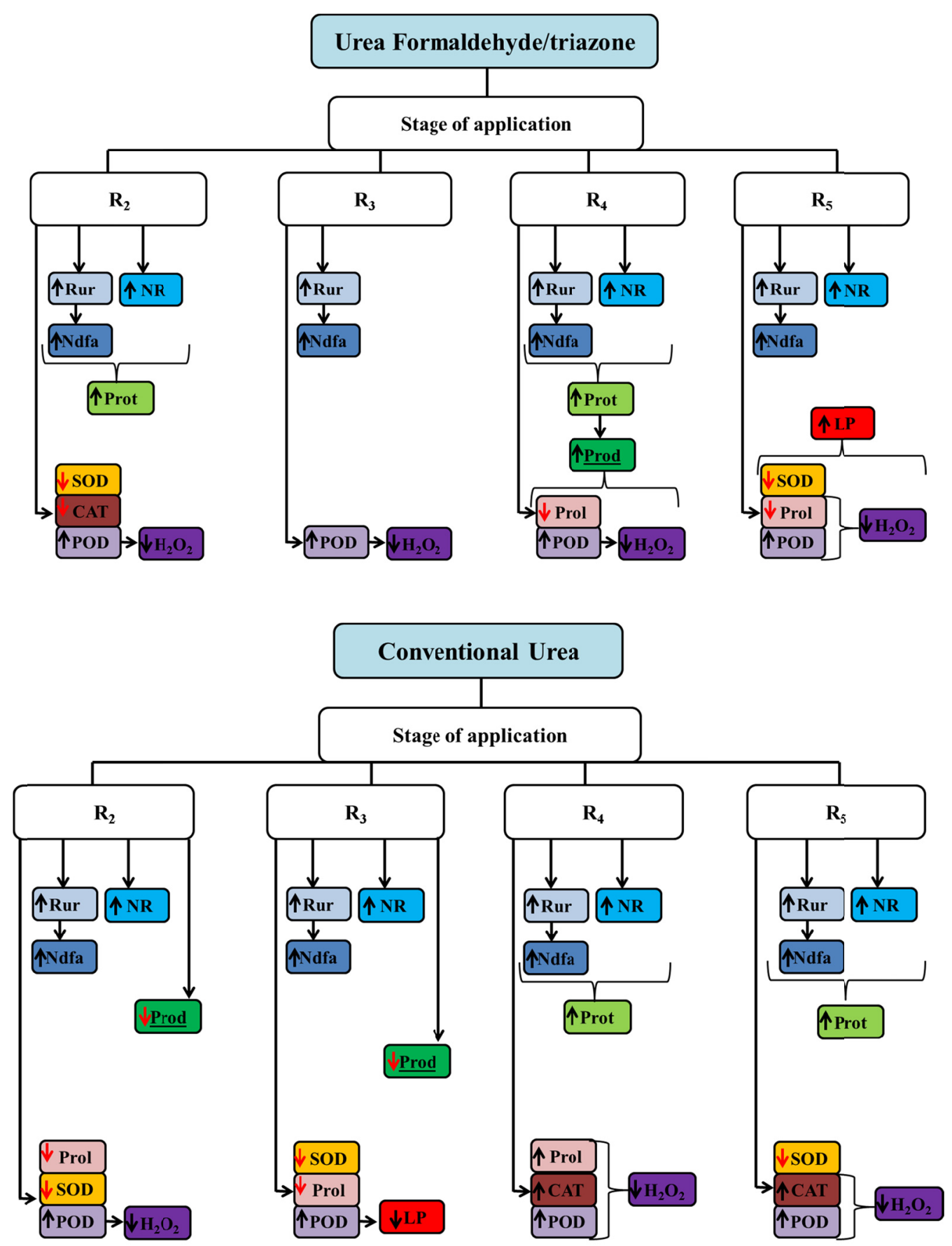

Figure 6. Summary of the effect of foliar application of urea formaldehyde/ triazone and conventional urea at $\mathrm{R}_{2}$, $\mathrm{R}_{3}, \mathrm{R}_{4}$, and $\mathrm{R}_{5}$ stages. Soybean leaf activity of nitrate reductase-NR, protein content-Prot, superoxide dismutase activity-SOD, peroxidase activity-POD, catalase activity-CAT, proline content-Prol, hydrogen peroxide content- $\mathrm{H}_{2} \mathrm{O}_{2}$, lipid peroxidation-PL, ureide content-Ure, relative abundance of ureide-Rur, percentage of nitrogen derived from the atmosphere-Ndfa, pod dry mass-PDM and productivity-Prod. Field experiment. Season 2018/2019. The summary of the results was produced by comparing the sources of $\mathrm{N}$ and stages of application with the control treatment 


\section{Discussion}

It was observed that the application of urea-formaldehyde/triazone increased nitrogen metabolism in all stages of application $\left(\mathrm{R}_{2}, \mathrm{R}_{3}, \mathrm{R}_{4}\right.$ and $\left.\mathrm{R}_{5}\right)$. As a result of increased nitrogen metabolism, higher leaf protein content was observed in stages $R_{2}$ and $R_{4}$ (Figures 4 and 6). These characteristics demonstrate the relationship between foliar application of low-dose nitrogen and signalling in plants. The concentration of nitrogen in the form of $\mathrm{NH}_{4}{ }^{+}$in plant tissue triggers the signalling role primarily because it induces the production of glutamate and glutamine (Coruzzi \& Bush, 2001) which can signal various physiological processes in plants (Forde \& Roberts, 2014; Weiland et al., 2015).

The increase in glutamate production in response to $\mathrm{NH}_{4}{ }^{+}$can play an important role in signalling in plants, as it is linked to physiological processes such as activation of permeate amino acids, calcium transporters, genes that are resistant to diseases and defend against stress, in addition to being involved in the activation of metabolism, transport, and growth genes (Kan et al., 2017). Glutamate also acts on the concentration of calcium that is propagated through phloem and intracellular channels (Toyota et al., 2018). According to Kang and Turano (2003), these signals can also alter the metabolism of carbon and nitrogen in plants. Therefore, the increase in nitrogen metabolism observed in our experiment may be a result of the indirect effect of the role of $\mathrm{NH}_{4}{ }^{+}$in plant signalling.

The maintenance of nitrogen and carbon metabolism must be strongly coordinated in plants in order to sustain plant growth, development, and productivity (Zheng, 2009). Plants with adequate nitrogen levels increase carbon metabolism, which can have an impact on increased productivity. The benefits of applying urea-formaldehyde/triazone were especially evident in the $\mathrm{R}_{4}$ stageresulting in an increase in the protein content in leaves and a $7 \%$ increase in yield in comparison to the control (Figures $4 \mathrm{H}$ and 5). There is a positive relationship between the concentration of protein in the leaves and yield (Figure 5). Plants with a higher protein concentration may show higher yield (Salvagiotti et al., 2008). These characteristics appear to be related to the gradual release of nitrogen combined with the period that precedes one of the stages of higher nitrogen demand in soybean plants. Triazone is responsible for the slow release of nitrogen (Widders, 1991) allowing the signalling process to occur gradually. This provides an increase in nitrogen metabolism and delay in leaf senescence, causing the plant to have greater nutritional support for fruit. Additionally, the availability of $\mathrm{N}$ in the leaves is essential for extending the grain filling period. Furthermore, there is a linear relationship between leaf $\mathrm{N}$ concentration in $\mathrm{R}_{5}$ and soybean productivity (Munier-Jolain et al., 1996; Shibles \& Sundberg, 1998).

Understanding the periods of higher nitrogen demand in soybean plants is essential to ensure a positive effect of foliar fertilization of this nutrient. According to Câmara (2014), soybean has two biological fixation peaks; the first at $\mathrm{R}_{1 / 2}$ at full bloom and the second at $\mathrm{R}_{5.1}$ and $\mathrm{R}_{5.2}$ in grain filling. According to the author, the biological fixation of nitrogen peaks occurs as a result of photosynthetic peaks that provide energy for functioning of the nodules.

The application of urea-formaldehyde/triazone was effective in increasing the antioxidant metabolism, with an increase in the activity of peroxidase enzyme and in protein content, and the consequent reduction in $\mathrm{H}_{2} \mathrm{O}_{2}$ content (Figure 4), which can also assist in increasing yield due to reduced plant stress. This effect can also be related to the induction of glutamate production from $\mathrm{NH}_{4}{ }^{+}$signalling. This amino acid increases antioxidant metabolism in plants (Mittler 2002; Gill \& Tuteja, 2010; Rejeb et al., 2014). The increase in the activity of antioxidant enzymes from glutamate was also observed by Teixeira et al. $(2017,2019)$.

The application of conventional urea provided positive results only in $\mathrm{R}_{4}$ and $\mathrm{R}_{5}$, in which it increased the metabolism of nitrogen and proteins, in addition to helping increase the antioxidant metabolism. This was reflected in the increase in yield by $4 \%$ compared to the control (Figure $4 \mathrm{H}$ ). The positive effect of urea in these two application phases can also be related to the signalling role provided by $\mathrm{NH}_{4}^{+}$, which modulates nitrogen metabolism (Kang \& Turano, 2003) and antioxidant metabolism leading to increased productivity. Conventional urea is rapidly absorbed by the leaves, so its application was only effective in periods close to the higher nitrogen demand in the soybean crop.

One of the first works that aimed to evaluate the effects of the application of conventional urea via leaves was carried out by Ashour and Thalooth (1983). These authors observed that the application of $1 \%$ urea in the $\mathrm{R}_{6}$ stage of soybean had an impact on the increase of fruiting, oil and protein content, and on pod mass.

It was shown that application of conventional urea reduced productivity by $6 \%$ and $4 \%$ when applied in stages $\mathrm{R}_{2}$ and $\mathrm{R}_{3}$, respectively, compared to control plants (Figure $\mathrm{H}$ ). These two stages do not correspond to higher nitrogen demand by plants and; therefore, this fact associated with the rapid absorption of conventional urea may have led to the toxic and negative effect of $\mathrm{NH}_{4}{ }^{+}$in plants. Due to the fact that these stages do not correspond to 
periods of higher nitrogen demand in plants (Câmara, 2014), the application may have led to a change in the carbon and nitrogen balance and the signalling process (Kang and Turano (2003), which leads to changes in the entire process of cellular metabolism, resulting in a negative impact on yield.

The use of low doses of nitrogen via foliar application in stages $\mathrm{R}_{4}$ and $\mathrm{R}_{5}$, increases nitrogen metabolism in soybean plants. The timing of the application directly affects the results of the application. Slow-release Nitrogen (urea-formaldehyde/triazone) presents better results when applied in stage $\mathrm{R}_{4}$. On average, the use of urea-formaldehyde/triazone increased soybean yield by approximately $1,44 \%$ and $1,58 \%$ compared with control and conventional urea, respectively. The late application of urea-formaldehyde/triazone $\left(\mathrm{R}_{5}\right)$ did not differ statistically from conventional urea on soybean yield, showing no benefits from the gradual release of $\mathrm{N}$ in that phenological stage. However, in other $\mathrm{N}$ application stages $\left(\mathrm{R}_{2}, \mathrm{R}_{3}\right.$ and $\left.\mathrm{R}_{4}\right)$, the urea-formaldehyde/triazone promotes a greater increase in productivity when compared to conventional urea, which allows greater flexibility in foliar application of $\mathrm{N}$, via urea-formaldehyde/triazone, when compared to conventional urea. The results suggest that further studies should be carried out at the genetic level, aiming to evaluate the role of foliar application of $\mathrm{NH}_{4}^{+}$, from a conventional source and gradual release. In this way, it will be possible to understand more clearly how this nutrient can signal changes in plants.

\section{References}

Alexieva, V., Sergiev, I., Mapelli, S., \& Karanov, E. (2001). The effect of drought and ultraviolet radiation on growth and stress markers in pea and wheat. Plant Cell Environment, 24, 1337-1344. https://doi.org/ 10.1046/j.1365-3040.2001.00778.x

Ashour, N. I., \& Thalooth, A. T. (1983). Effect of soil and foliar application of nitrogen during pod development on the yield of soybean (Glycine max (L.) Merr.) plants. Field Crops Research, 6, 261-266. https://doi.org/ 10.1016/0378-4290(83)90066-7

Bates, L., Waldren, R. P., \& Teare, I. D. (1973). Rapid determination of free proline for water-stress studies. Plant Soil, 39, 205-207. https://doi.org/10.1007/BF00018060

Beauchamp, C., \& Fridovich, I. (1971). Superoxide dismutase: improved assays and applicable to acrylamide gels. Analytical Biochemistry, 44(1), 276-287. https://doi.org/10.1016/0003-2697(71)90370-8

Bondada, B. R., Syvertsen, J. P., \& Albrigo, L. G. (2001). Urea nitrogen uptake by citrus leaves. Hortscience, 36(6), 1061-1065. https://doi.org/10.21273/HORTSCI.36.6.1061

Borkert, C. M., Yorinori, J. T., Ferreira, B. S. C., Almeida, A. M. R., Ferreira, L. P., \& Sfredo, G. J. (1994). Seja o doutor da sua soja. Arquivo do Agrônomo (Número 5). Informações Agronômicas (Número 66). Potafos.

Câmara, G. M. S. (2014). Fixação biológica de nitrogênio em Soja (Informações Agronômicas, 147). Piracicaba: IPNI.

Cataldo, D. A., Haroon, M., Schrader, L. E., \& Youngs, V. L. (1975). Rapid colorimetric determination of nitrate in plant tissue by nitration of salicylic acid. Communications in Soil Science and Plant Analysis, 6, 71-80. https://doi.org/10.1080/00103627509366547

Clapp, J. G. (2001). Urea-Triazone N Characteristics and uses. The Scientific World, 1, 103-107. https://doi.org/ $10.1100 /$ tsw.2001.356

Clapp, J. G., \& Parham, T. M. (1991). Properties and uses of liquid urea-triazone-based nitrogen fertilizers. Fertilizer Research, 28, 229-232. https://doi.org/10.1007/BF01049755

CONAB (Companhia Nacional de Abastecimento). (2021). Acompanhamento da safra brasileira. Brasília, Brazil.

Coruzzi, G., \& Bush, D. R. (2001). Nitrogen and carbon nutrient and metabolite signaling in plants. Plant Physiology, 125(1), 61-64. https://doi.org/10.1104/pp.125.1.61

Forde, B. G., \& Roberts, M. R. (2014). Glutamate receptor-like channels in plants: a role as amino acid sensors in plant defense? F1000Prime Reports, 37, 6-37. https://doi/10.12703/P6-37

Gill, S., \& Tuteja, N. (2010). Reactive oxygen species and antioxidant machinery in abiotic stress tolerance in crop plants. Plant Physiology and Biochemistry, 48, 909-930. https://doi.org/10.1016/j.plaphy.2010.08.016

Heath, R. L., \& Packer, L. (1968). Photoperoxidation in isolated chloroplasts. I. Kinetics and stoichiometry of fatty acid peroxidation. Archives of Biochemistry and Biophysics, 125, 189-198. https://doi.org/10.1016/ 0003-9861(68)90654-1 
Herridge, D. F. (1984). Effects of nitrate and plant development on the abundance of nitrogenous solutes in root bleeding and vacuum extracted exudates of soybean. Crop Science, 25, 173-179. https://doi.org/10.2135/ cropsci1984.0011183X002400010041x

Herridge, D. F., \& Peoples, M. B. (1990). The ureide assay for measuring nitrogen fixation by nodulated soybean calibrated by $15 \mathrm{~N}$ methods. Plant Physiology, 93, 495-503. https://doi.org/10.1104/pp.93.2.495

Hungria, M., Campo, R. J., \& Mendes, I. C. (2001). Fixação simbiótica do nitrogênio na cultura da soja. Embrapa Soja, Londrina, PR, Brazil.

Hungria, M., Franchini, J. C., Campo, R. J., Crispino, C. C., Moraes, J. Z., Sibaldelli, R. N. R., ... Arihara, J. (2006). Nitrogen nutrition of soybean in Brazil: Contributions of biological $\mathrm{N}_{2}$ fixation and of $\mathrm{N}$ fertilizer to grain yield. Canadian Journal of Plant Science, 86(4), 927-939. https://doi.org/10.4141/P05-098

Kan, C. C., Chung, T. Y., Wu, H. Y., Juo, Y. A., \& Hsieh, M. H. (2017). Exogenous glutamate rapidly induces the expression of genes involved in metabolism and defense responses in rice roots. BMC Genomics, 18, 186. https://doi.org/10.1186/s12864-017-3588-7

Kang, J. M., \& Turano, F. J. (2003). The putative glutamate receptor 1.1 (AtGLR1.1) functions as a regulator of carbon and nitrogen metabolism in Arabidopsis thaliana. Proceedings of the National Academy of Sciences USA, 100, 6872-6877. https://doi.org/10.1073/pnas.1030961100

Kar, M., \& Mishra, D. (1976). Catalase, peroxidase, and polyphenol oxidase activities during rice leaf senescence. Plant Physiology, 57(2), 315-319. https://doi.org/10.1104/pp.57.2.315

Marcon, E. C., Romio, S. C., Maccari, V. M., Klein, C., \& Lájus, C. R. (2017). Uso de diferentes fontes de nitrogênio na cultura da soja. Revista Thema, 14(2), 298-308. https://doi.org/10.15536/thema.14.2017. 298-308.427

Mendes, I. C., Reis Junior, F. B., Hungria, M., Sousa, D. M. G., \& Campo, R. J. (2008). Adubação nitrogenada suplementar tardia em soja cultivada em latossolos do Cerrado [Late suplementar nitrogen fertilization in soybean cultivated in oxisoils of Cerrado]. Pesquisa Agropecuária Brasileira, 43(8), 1053-1060. https://doi.org/10.1590/S0100-204X2008000800015

Mittler, R. (2002). Oxidative stress, antioxidants and stress tolerance. Trends Plant Science, 7, 405-410. https://doi.org/10.1016/s1360-1385(02)02312-9

Moreno, G., Albrecht, A. J. P., Albrecht, L. P., Pivetta, L. A., Tessele, A., Lorenzetti, J. B., \& Furtado, R. C. N. (2018). Application of nitrogen fertilizer in high-demand stages of soybean and its effects on yield perform. Australian Journal Crop Science, 12(1), 16-21. doi:10.21475/ajcs.18.12.01.pne507

Mulder, E. G., Boxma, R., \& Veen, W. L. V. (1959). The effect of molybdenum and nitrogen deficiencies on nitrate reduction in plant tissues. Plant and Soil, 10, 335-355. https://doi.org/10.1007/BF01666209

Munier, J. N. G., Ney, B., \& Duthion, C. (1996). Termination of seed growth in relation to nitrogen content of vegetative parts in soybean plants. European Journal of Agronomy, 5, 219-225. https://doi.org/10.1016/ S1161-0301(96)02025-4

Pacentchuk, F., Novakowiski, J. H., \& Sandini, I. E. (2014). Nitrogênio complementar via foliar nas culturas do milho, soja e feijão: doses e estádio fenológicos de aplicação. Plantio Direto, XXIV.

Peixoto, H. P. P., Cambraia, J., Sant'ana, R., Mosquim, P. R., \& Moreira, A. M. (1999). Aluminum effects on lipid peroxidation and the activities of enzymes of oxidative metabolism in sorghum. Brazilian Journal of Plant Physiology, 11(3), 137-143.

Pell, M. C., Finlayson, B. L., \& McMahon, T. A. (2007). Updated world map of the KöppenGeiger. Hydrology and Earth System Sciences, 4(2), 439-473. https://doi.org/10.5194/hess-11-1633-2007

Pierozan Junior, C., Favarin, J. L., Lago, B. C., Almeida, R. E. M., Oliveira, S. M. de, Trivelin, P. C. O., ... Gilabel, A. P. (2020). Nitrogen fertilizer recovery and partitioning related to soybean yield. The Journal of Soil Science and Plant Nutrition, 2. https://doi.org/10.1007/s42729-020-00322-x

Prado, R. M., Franco, C. F., \& Puga, A. P. (2010). Deficiências de macronutrientes em plantas de soja cv. BRSMG 68 cultivada em solução nutritiva. Comunicata Scientiae, 1(2), 114-119.

Rejeb, K. B., Abdelly, C., \& Savouré, A. (2014). How reactive oxygen species and proline face stress together. Plant Physiology and Biochemistry, 80, 278-284. https://doi.org/10.1016/j.plaphy.2014.04.007 
Salvagiotti, F., Cassman, K. G., Sprecht, J. E., Walters, D. T., Weiss, A., \& Dobermann, A. (2008). Nitrogen uptake, fixation and response to fertilizer $\mathrm{N}$ in soybeans: A review. Field Crops Research, 108, 1-13. https://doi.org/10.1016/j.fcr.2008.03.001

Shibles, R., \& Sendberg, D. N. (1998). Relation of leaf nitrogen content and other traits with seed yield of soybean. Plant Production Science, 1, 3-7. https://doi.org/10.1626/pps.1.3

Taiz, L., Zeiger, E., Moller, I. M., \& Murphy, A. (2017). Fisiologia e desenvolvimento vegetal (6th ed., p. 888). Porto Alegre: Artmed.

Teisseire, H., \& Guy, V. (2000). Copper-induced changes in antioxidant enzymes activities in fronds of duckweed (Lemna minor), Plant Science, 153, 65-72. https://doi.org/10.1016/S0168-9452(99)00257-5

Teixeira, W. F., Fagan, E. B., Soares, L. H., Umburanas, R. C., Reichardt, K., \& Dourado-Neto, D. (2017). Foliar and seed application of amino acids affects the antioxidant metabolism of the soybean crop. Frontiers in Plant Science, 8, 1-14. https://doi.org/10.3389/fpls.2017.00327

Teixeira, W. F., Soares, L. H., Fagan, E. B., Mello, S. da C., Reichardt, K., \& Dourado-Neto, D. (2019). Amino acids as stress reducers in soybean plant growth under different water-deficit conditions. Journal of Plant Growth Regulation, 1-15. https://doi.org/10.1007/s00344-019-10032-z

Toyota, M., Spencer, D., Sawai-Toyota, S., Jiaqi, W., Zhang, T., Koo, A. J., ... Gilroy, S. (2018). Glutamate triggers long-distance, calcium-based plant defense signaling. Science, 14(361), 1112-1115. https://doi.org/ $10.1126 /$ science.aat 7744

Weiland, M., Mancuso, S., \& Baluska, F. (2015). Signalling via glutamate and GLRs in Arabidopsis thaliana. Functional Plant Biology, 23, 1-25. https://doi.org/10.1071/FP15109

Widders, I. E. (1991). Absorption and traslocation of foliar applied triazone-N as compared to other nitrogen source in tomato. Journal of Plant Nutrition, 14(10), 1035-1045. https://doi.org/10.1080/0190416910 9364263

Wilson, E. W., Rowntree, S. C., Suhre, J. J., Weidenbenner, N. H., Conley, S. P., Davis, V. M., ... Casteel, S. N. (2014). Genetic gain $\times$ management interactions in soybean. II. Nitrogen utilization. Crop Science, 54(1), 340-348. https://doi.org/10.2135/cropsci2013.05.0339

Yemm, E. W., Cocking, E. C. (1955). The determination of amino acids with ninhydrin. Analyst, 80, $209-213$. https://doi.org/10.1039/AN9558000209

Young, E. G., Conway, C. F. (1942). On the estimation of allantoin by the Rimini-Schryver reaction. The Journal of Biological Chemistry, 142, 839-853. https://doi.org/10.1016/S0021-9258(18)45082-X

Zheng, Z.-L. (2009). Carbon and nitrogen nutrient balance signaling in plants. Plant Signaling \& Behavior, 4(7), 584-59. https://doi.org/10.4161/psb.4.7.8540

\section{Copyrights}

Copyright for this article is retained by the author(s), with first publication rights granted to the journal.

This is an open-access article distributed under the terms and conditions of the Creative Commons Attribution license (http://creativecommons.org/licenses/by/4.0/). 